\title{
Tracing Bloodlines: Kinship and Reproduction Under Investigation in CSI: Crime Scene Investigation
}

\section{SOFIA BULL}

\begin{abstract}
This article examines discourses on kinship and reproduction in the forensic crime drama CSI: Crime Scene Investigation (2000-). I argue that the programme stages a visual materialization of genetic kinship in order to assert its importance as a crucial type of forensic evidence, which evokes the traditional Darwinian framework of genealogy for understanding biological kinship as a substantial and enduring trace between generations. However, I show that CSI also participates in contemporary bioethical debates about new genetic and biomedical technologies that increasingly allow us to interfere in the human reproduction process. I conclude that while the programme engages with an emergent post-genomic respatialization of genealogy and acknowledges that the concept of kinship is increasingly being redefined, $C S I$ is still heavily invested in a normative understanding of sexual reproduction as a 'natural fact of life' and inadvertently constructs the nuclear family structure as an ideal framework for procreation.
\end{abstract}

\section{KEYWORDS}

TV; kinship; family; reproduction; genetics; forensic science

It is well known that the ties between the television medium and the concept of the family are close and enduring. On the one hand, the family has long been understood as a crucial cultural context for television reception. As Lynn Spigel's research has shown, the medium quickly became associated with family life and domestic ideals after the Second World War. Although the popular press ascribed highly contradictory meanings to television they often focused on how the new medium would impact the normative family unit (Spigel 1992). Furthermore, 'family viewing' has proved to be a persistent concept that still circulates widely and continues to capture the interest of many television scholars (Bryant 1990; Lull 1990; Mahajan and Luthra 1993; Douglas 2003; Bryant \& Bryant 2001).

On the other hand, 'the family' has also figured prominently on television and the interdisciplinary field of television studies has produced numerous studies of the medium's representation of family structures and familial relationships, from the 1950s until the present day. While this body of scholarly work has examined ideas about kinship articulated across a range of different television genres and formats, it has traditionally focused on family-centric fictional programming (Pingree \& Thompson 1990; Moore 1992; Leibman 1995; Linné \& Hartmann 1986; Taylor 1989; Robinson \& Skill 2001; Dates \& Stroman 2001; Douglas 2001; Keeler 2010) and there has been a particularly strong interest in the sitcom or the 'domestic comedy' as an important site for negotiating ideas about kinship (Cantor 1991; Reep \& Dambrot, 1994; Douglas \& Olson 1995; Douglas 1996; Sandell 1998; Douglas 2003). More recent scholarship has also turned the spotlight onto family-centric documentary and reality programming (Murray 1999; Rupert \& Puckett 2010; Holmes 2010; Edwards 2010; Villarejo 2014; Pramaggiore \& Negra 2014; Oueliette 2014; Stephens 2014).

Adding to this extensive body of work, this article turns its attention to a genre that is traditionally far less focused on domestic issues as such and has therefore fairly rarely been discussed as significantly contributing to discourses on kinship: namely the crime drama. However, as this article will show, ideas about kinship are not only articulated by 
direct figurations of 'the family', but also circulate via narratives and imagery dealing with biological bonds, ancestry and reproduction. I will specifically examine how CSI: Crime Scene Investigation (2000-) participates in contemporary cultural debates about kinship relationships, family structures and reproduction practices. While it can be argued that CSI: Crime Scene Investigation (henceforth abbreviated as CSI) emulates some of the conventions and formulas of family-centric programmes through its construction of a group of colleagues as a chosen 'work family' (Taylor 1989; Sandell 1998, Heintz-Knowles 2001; Burr \& Jarvis 2005, Burr \& Jarvis 2007, Lavigne 2009: 385), I will in this article primarily discuss the programme's crime plots and depiction of forensic practices as participating in contemporary cultural debates about kinship.

In doing so I draw on earlier scholarly work that in passing has indicated that many forms of crime television are characterized by an inadvertent investment in the ideal of the nuclear family and traditional 'family values'. Familial relationships have, for example, often featured in reality crime narratives as an idealized framework for the victim, providing a safe haven away from the dangers of the surrounding world (Jermyn 2007: 91-100). Conversely, many crime dramas have instead expressed worries about dysfunctional family relationships as a site or cause of criminal behaviour (Rapping 2003: 169-73, Young 1996: 146-74). In these cases the traditional family unit instead figures as a nostalgic absence and law enforcement is constructed as a moral guardian attempting to restore the ideal domestic equilibrium. However, CSI does not simply follow one of these more long-running traditions. While I will argue that the programme articulates a normative investment in the nuclear family structure and monogamous sexual practices, I will specifically examine these ideas as tied to decidedly contemporary cultural debates surrounding recent developments in biomedicine and genetics, namely genealogical DNA tests and assisted reproduction technologies.

I will begin by examining CSI's celebratory portrayal of DNA technology, which constitutes genetic kinship as a significant form of information for solving crime. I will argue that CSI's repeated use of certain types of visual iconography (physical markers of likeness, blood and family trees) materializes genetic kinship in order to assert its importance as a crucial type of forensic evidence. This process of making kinship matter calls upon the traditional Darwinian framework of genealogy as a basis for understanding biological kinship as a substantial and enduring trace between generations, which constructs biological bonds as significant even in cases where two relatives lack the expected social relationship. I will then move on to map CSI's participation in contemporary bioethical debates about new genetic and biomedical technologies that allow us to increasingly interfere in the human reproduction process. I specifically examine episodes of CSI that discuss assisted reproduction practices, foetal scanning and non-reproductive sexual acts. I conclude that while the programme acknowledges that kinship is in the process of being redefined, it is still heavily invested in a normative understanding of sexual reproduction as a 'natural fact of life' and inadvertently constructs the nuclear family structure as an ideal framework for procreation. This study thus attempts to acknowledge that televisual representations of 'the family' and 'family values' are rooted in wider socio-historically specific frameworks for understanding kinship, and furthermore, that there is a need to further investigate how current imaginations of kinship relate to new developments in biomedicine and genetics. 
This is a pre-copy edited version of an article accepted for publication in Journal of Popular Television (Volume 2, Issue 2, October 2014) following peer-review. The definitive publisher authenticated version is available from: http://www.intellectbooks.co.uk/journals/view-Article,id=18491/

\section{Making Genetic Kinship Matter as Forensic Evidence}

CSI's figuration of familial relationships and reproduction practices is closely intertwined with the programme's construction of DNA evidence as an exceptionally reliable and useful source of information with which many crimes can be solved. Based on a quantitative analysis of 51 randomly picked episodes from seasons 1-6 of CSI, Barbara Ley, Nathalie Jankowski and Paul R. Brewer have concluded that 39 per cent of the episodes feature cases where DNA evidence is used to help solve the crime (Ley, Jankowski \& Brewer 2010: 10). DNA evidence often figures as a kind of deus ex machina: it is the ultimate proof that provides the forensic investigators with seemingly unquestionable facts about the crime and usually prompts a confession from the perpetrator. Crucially, DNA evidence is constructed as a highly versatile source of knowledge. The programme envisions DNA as a blueprint harbouring the true identity of perpetrators, victims and witnesses alike, as well as a map tracing their movements over vast temporal and geographical spaces. Furthermore, DNA evidence is also used as a proof of social and biological relationships, providing information about both sexual connections and genealogical bonds.

CSI generally portrays all types of DNA evidence in ways that emphasize the smallness of the molecular world. The programme's characteristic snap zoom effect is, for example, repeatedly used to display DNA strings in extreme close-up. While these fantastic microscopic shots celebrate the ability of new forensic technologies to render even the smallest clue visible, they also inadvertently emphasize the relative invisibility of this type of evidence. This tension is even more tangible in scenes imaging the forensic process of collecting and analysing biological samples in the hunt for DNA evidence. Such scenes use the iconography of cotton swabs, tiny glass vials, petri dishes and test result printouts to highlight the scientific sophistication of this process, but this imagery also accentuates the fact that DNA molecules, genes and chromosomes are completely invisible to human sight. This involves a potential risk, as the tendency to highlight the intangible nature of DNA evidence might undermine the programme's narrative assertion that DNA is a substantial source of reliable information.

\section{[Figure 1: Gil Grissom collecting DNA evidence in 'Bloodlines'.]}

This threat is, however, largely deflected by additional visualisation practices that conversely construct DNA as a concretely material, corporeal and enduring trace. In the particular cases where DNA evidence is used as proof of kinship, CSI calls upon a number of long-running cultural symbols associated with biological substance and endurance in order to make genetic kinship (into) matter. This has a crucial narrative function, as the episodes where proof of kinship is needed are often thematically focused on the possibility that we might not know who we are related to and what our ancestry is. In other words, these are plots where the forensic scientists must establish whether two people are related or not, either because this information is concealed or the people themselves are unaware of being relatives. Within this context much effort is poured into the construction of the biological bond as both tangible and significant, even when it is unknown.

The importance of kinship is, for example, asserted by using a range of mirroring techniques to exaggerate markers of likeness between characters that are related. Visual and narrative emphasis is typically placed on physical traits such as eye and hair colour, which are commonly understood as being hereditary. By means of various editing, blocking, and acting techniques, related characters are not only identified by physical resemblance but also through behavioural similarities. The episode 'Happenstance', for example, opens with a montage sequence that abridges the final hour in the lives of two 
This is a pre-copy edited version of an article accepted for publication in Journal of Popular Television (Volume 2, Issue 2, October 2014) following peer-review. The definitive publisher authenticated version is available from: http://www.intellectbooks.co.uk/journals/view-Article,id=18491/

estranged identical twins. By crosscutting between the two women visually mirroring each other's movements, it is established that even though they lead drastically different lifestyles (one is a housewife doing the dishes, while the other is a career woman preparing for a hot date), their shared biological substance still has a significant physical impact: they both look the same and act in synchronization.

[Figures 2 and 3: Mirrored twin sisters in the opening sequence of 'Happenstance'.]

After both women have been found dead, the forensic investigation continues to map the similarities between them; they frequented the same dry cleaner, they had similar handwriting and shared the same taste in watches and nail polish. Crucially, the investigation reveals that the sisters had been separated at birth and grew up in completely different environments, which in turn identifies their similarities as purely the result of 'nature', not 'nurture'. Their shared genetic substance is thus constructed as having a decidedly material and concrete presence, even in cases such as this where the biological bond lacks social significance for the related individuals.

This process of substantiation is similarly enacted through the programme's symbolic use of blood, which evokes the long-running cultural understanding of blood as an emblem of kinship relationships (Schneider 1980: 23-4, Carsten 2001: 31-2; Weston 2001: 147-74). Blood is by no means used as a symbol of kinship in all CSI episodes, but spectacular displays of large amounts of blood are often given this particular function in plotlines that thematically focus on problematic familial relationships. The expressionistic colour scheme of CSI means that blood often is given a fantastically bright red colour, which renders it a source of DNA that - unlike most other biological traces - is clearly visible to the human eye. The cinematography and special effects used to emulate blood also tend to enhance the appearance of its density and stickiness, which in extension provides the notion of genetic kinship with a more concrete sense of materiality.

One telling example of this is the crime scene featured in 'Spark of Life', an episode in which a woman's strong wishes for a biological child is presented as a catalyst for multiple murders. The forensic scientists' slow movements through a dark suburban house are accompanied by an eerie, unnaturally loud dripping sound, which anticipates the discovery of a blood-drenched corpse lying on a flight of stairs. The camera first catches a glimpse of bright red blood at the bottom of the stairs and then slowly tracks the multiple blood trails back to their source. A medium close-up allows us to clearly see the blood seeping down a lifeless arm and falling off the fingertips. This is followed by an extreme close-up, filmed in slow motion, displaying one blood-drop as it falls into a bowl of water placed underneath the body. As the drop impacts the surface it is propelled back upwards, its round red shape still clearly distinguishable against the water. This shot effectively connotes the saying 'blood is thicker than water'. The soundtrack, cinematography and special effects effectively interact to create a heightened sense of the texture and movement of the blood, which calls forth the concepts of 'bloodlines' or 'blood ties'; notions that construct biological kinship as a substantial bond that can never be terminated or severed, thus remaining significant even in death (Schneider 1980: 23-4).

[Figure 4: The materiality of a blood drop on display in 'Spark of Life'.]

The long-running idea that kinship is a highly resilient and enduring biological substance that is transferred from generation to generation is crucial for CSI's portrayal of DNA as an exceptionally useful source of knowledge about human relationships. This notion 
is not only conjured up by the symbolic use of blood, but also through a repeated use of the iconography of the family tree, which is commonly used in both science and popular culture precisely to imagine kinship as being a spatially dispersed, but highly durable, linkage abridging both time and space. Many of CSI's forensic investigations trace ancestry and family histories in ways that mirror the increasingly popular practice of creating one's own family tree (Nash 2002: 27-52, Nash 2005: 449-62). The forensic scientists are repeatedly seen using online resources such as document archives or family tree generators, tools familiar to anyone dabbling in amateur genealogy.

When the forensic scientists investigate the murder of a prominent genealogistfor-hire in the aptly titled episode 'Genetic Disorder', forensic analysis and genealogical research are explicitly presented as kindred practices sharing the same fundamental belief that biological kinship is a fundamental marker of identity. However, the comparison also identifies forensic science as a far more technologically advanced practice that can produce more reliable and significant information about kinship. While the investigators initially consult a genealogist, it is DNA technology that ultimately solves the puzzle. In an unexpected plot twist the DNA evidence recovered from a murder weapon initially fails to produce a DNA match in the database of convicted criminals (CODIS). A lab technician suggests that they should expand their search to include an entire family. This method not only identifies the perpetrator, but also helps explain the motive: the genealogist was killed because he uncovered a family history of incest. Crucially, the matching process is illustrated with a CGI animation of a 'DNA family tree', imagined as a swirling double helix with anonymous mug shots attached here and there. The camera tracks the molecule in an upwards-travelling pan, figuratively tracing the genetic lineage back through past generations and exposing the tangled kinship relationships that have previously been concealed.

\section{[Figure 5: CGI animation of a 'DNA family tree' in 'Genetic Disorder'.]}

Crucially, the figuration of this genetic family tree clearly evokes the notion of genealogical descent as a 'vertical spine', so typical to the Darwinian framework of understanding biological life (Strathern 1992; Franklin 2000: 218). As Sarah Franklin has explained, the contemporary understanding of genetic kinship is based on life being framed as a continuous and unified vertical passage of generations that should be distinctly linear and structured by natural selection (Franklin 2000: 217-18). She specifies that:

Importantly, for Darwin, life itself is vertically propriocentric: its progressive orientation is always in forward gear, and its ontological constitution as a force or principle of animate vitality is always composed through descent lines criss-crossed at the point of reproduction, but pointing downwards. Like the early Ford motor car, Darwin's genealogy didn’t go into reverse. (Franklin 2000: 218)

This traditional genealogical framework still informs popular discourses on kinship, including CSI's materialization of DNA evidence as proof of kinship. In 'Genetic Disorder', CSI expresses a deep-seated cultural anxiety rooted in the Darwinian genealogy; namely that any kind of reproductive practice that halts the forward driving progression of descent is dangerously 'unnatural'. Tellingly, this case of incest is presented as a mutual and voluntary sexual act. Thus, it is primarily problematized as an 'unnatural' mixing of genetic substance, rather than a case of sexual violence. This is by no means the only CSI episode where certain reproduction practices are criminalized on the basis of the traditional genealogical framework. As I will outline in the following sections, the programme repeatedly deals with reproduction practices that potentially cause a deviation from what is perceived as the 'natural order' of vertical descent. 


\section{Crimes Against the 'Natural Facts of Life'}

In addition to worrying about inbreeding, CSI also constructs biomedically assisted reproduction practices as similarly undermining the traditional genealogical framework. This issue is, for example, discussed in the episode 'Secrets and Flies', in which the forensic scientists investigate the murder of a woman who has given birth to a child by 'adopting' a fertilized embryo through a pro-life organisation that finds mothers for the 'lives' left over from in vitro fertilization treatments. The opening teaser effectively establishes the episode's treatment of assisted reproduction practices and their impact on the notion of kinship. It begins with six aerial shots of Las Vegas, each crosscut with CGI animations of the human reproduction process inside a womb. Abridging the chronology of conception and foetal development, these are snap-shots of the sperms' journey after ejaculation, the fertilisation of the egg, the cleavage and gestation. It ends with a travelling close-up shot, smoothly moving along the body of the almost fully developed foetus inside the amniotic sac, finally fading into a photographic close-up of the face of a toddler standing inside a playpen. The camera then zooms out to reveal the dead body of his mother, lying motionless on the floor.

\section{[Figures 6 and 7: Imagery of the human reproduction process in 'Secrets and Flies'.]}

This sequence emulates science photojournalist Lennart Nilsson's groundbreaking photographs and films of the human reproduction process. Nilsson's imagery has been widely reproduced and imitated after Life magazine first published a series of photos from his book A Child is Born in Life (Nilsson and Ingelman-Sundberg, 1965). Furthermore, his television documentaries The Miracle of Life (Lennart Nilsson, Nova/PBS, 1983), The Miracle of Love (Lennart Nilsson, SVT/PBS, 2000) and Life's Greatest Miracle (Lennart Nilsson, Nova/PBS, 2001) have been distributed worldwide. As is often the case when CSI draws on scientific imagery, the programme revamps the visual language in accordance with its highly spectacular televisual look (Caldwell 1995). More dynamic cinematography and CGI effects supersede Nilsson's comparatively flat and sluggish microscopic imagery in ways that amplify the sense of speed and space. Not only does the camera show the sperm rapidly approach from a distance and disappear into a vibrantly red cavity, but the camera itself dashes towards the egg and then flies along the surface, zigzagging in between the sperm frenetically struggling to penetrate it. Through this action-packed version of the reproductive process, CSI further enhances the sense of fascination and wonder at 'life itself' already conveyed in Nilsson's films.

However, while Nilsson's films frame the corporeal micro-level of the biological reproduction process with normative narratives of heterosexual parenthood, the imagery in 'Secrets and Flies' is curiously disembodied. Rather than imaging the parents of the growing foetus, it is the hyperbole of the city of Las Vegas that frames the reproduction process. With its reputation as a poster-city of postmodernity - the epitome of all things fake and plastic - the setting of Las Vegas results in a noteworthy denaturalisation of the reproduction process (Belk 1996: 89-111). The inserts of Sin City evoke an artificial and artefactual quality that function as a premonition of the plotline's central twist: the murdered mother is not genetically related to her son and she was murdered by his biological grandmother who wanted him reunited with his biological parents. By literally equating the grandmother's wish to align the child's social and genetic kinship bonds with murder, the 
This is a pre-copy edited version of an article accepted for publication in Journal of Popular Television (Volume 2, Issue 2, October 2014) following peer-review. The definitive publisher authenticated version is available from: http://www.intellectbooks.co.uk/journals/view-Article,id=18491/

episode does problematize the essentialist understanding of genetic kinship as always determining social bonds. As viewers we are set up to emphasize with the 'adoptive' mother; the investigation establishes that she had been an amazing mother with a strong bond to her child, which acknowledges that kinship is socially constructed, and furthermore, that advances in assisted reproduction technologies force us to reconsider the old 'truths' of the Darwinian framework.

In episodes such as this, CSI clearly engages with a wider discursive shift whereby developments in the fields of genetics and biomedicine are engendering an emergent redefinition of the concept of kinship (Franklin 2000: 217-22, Haraway 1997: 52-6, 213-23, Stacey 2010: 32-34). As explained by Sarah Franklin, this redefinition of kinship is a result of a general and more long-running process of geneticization, through which biological life has been become understood as a code, or a 'sequence of letters' (Franklin 2000: 218-19). This tendency has intensified since the discovery of the structure of the double helix in the 1960s, but the early 2000s has witnessed a gradual move beyond traditional genetic essentialism and reductionism. The resent emergence of a 'post-genomic' systems biology has resulted in an increased emphasis on complex interactions on the level of genes and molecules, and the possibility for humans to freely and endlessly recombine the genetic code (Keller 2005: 3-6, Rose 2007: 17-21, 40-7, Franklin 2000: 190).

Within this emergent post-genomic discourse, the classic linear and vertical spatial structure of the Darwinian genealogy is increasingly becoming re-imagined and replaced with the notion of 'the gene pool', from which genetic codes from different individuals, generations and even species can be recombined, in accordance with an artefactual 'mix and match' sensibility. Franklin argues that:

\begin{abstract}
Recombination need no longer operate intergenerationally, through the downward (as if gravitational) linear flow of descent. Selection need no longer operate like a weir across the river of life. Indeed the river need no longer 'flow' at all since its mere width becomes at any given moment a source of greater horizontal variation than it ever was constrained within narrow, lineal, canal-like passages of gene transfer, tapering to their narrowest width at the point of recombination. As sexual reproduction is above all else the mechanism for genetic recombination under Darwin's scheme, so it is as definitely rendered insignificant by the advent of assisted heredity, cloned transgenics and the entire millennial menagerie of unfamiliar kinds. (Franklin 2000: 218)
\end{abstract}

To summarize, Franklin convincingly argues that genealogy is in the process of being respatialized, de-sexualized and turned artefactual. (Franklin 2000: 218-19) In other words, the vertical bloodline of Darwinian genealogy can be replaced with constructed kinship ties that are fundamentally different in structure and significance; kinship can now become organized along a horizontal axis rather than vertical, produced in a laboratory and under human control (Haraway 1997: 134).

In episodes such as 'Secrets and Flies', CSI acknowledges that new assisted reproduction technologies question traditional definitions of biological kinship and that this, by extension, encourages a redefinition of socially constructed kinship roles and family structures. However, the programme's overall investment in the Darwinian framework of genealogy ultimately constructs assisted reproduction technologies as producing new forms of kinship that are problematically human-made and artificial. This rather apprehensive perspective is more explicitly articulated in a number of episodes that express more general worries about human aspirations to interfere with the sexual reproduction process. CSI features numerous plotlines that can be read as bioethical discussions of whether we should be able to stop certain hereditary genetic traits from being transferred onto the next generation. For example, in both 'A Little Murder' and 'Werewolves' the victims have been murdered by 
This is a pre-copy edited version of an article accepted for publication in Journal of Popular Television (Volume 2, Issue 2, October 2014) following peer-review. The definitive publisher authenticated version is available from: http://www.intellectbooks.co.uk/journals/view-Article,id=18491/

their in-laws in order to stop them from procreating and thus having a certain genetic traits dwarfism and hypertrichosis respectively - transferred to future generation of the family. Similarly, 'Feeling the Heat' and 'Still Life' both feature parents that murder their own children because they believe their genetic heritage will cause them harm in the future. Hence, in these episodes the act of murder stands in for the reproductive choices we are increasingly faced with through developments in genetic scanning and assisted reproduction.

[Figures 8 and 9: Murders that stand in for reproductive choices in 'A Little Murder' and 'Warewolves'.]

The programme makes explicitly references to genetics when the hereditary nature of certain physical traits are presented as a motive for murder. For example, in 'Feeling the Heat' we learn that the parents who are under suspicion of having killed their infant son had been told by their family physician that as carriers of the genetic and degenerative TaySachs disease there was a 25 per cent chance their son was born with it. Similarly, in 'A Little Murder' a medical language of risk and probability is also used when describing the averageheight offspring of two parents carrying the dwarfism allele as a 'genetic miracle' and a ' $1 / 4$ shot'. The perpetrator's dislike of his daughter's choice of husband is, as pointed out by the head forensic scientist Gil Grissom, solely based on genetics: there would have been a 50 per cent chance their baby would be a dwarf.

In both these cases, the motivations behind the murders are thus rooted within a traditional genetic framework where genes are understood as blueprints of future bodies. However, it is primarily the incentive to intervene and hinder these futures that are problematized through the alignment of such practices with the act of murder. Hence, CSI's general investment in essentialist genetics brings with it a sensibility that ultimately condemns attempts to intervene in the biological process of sexual reproduction. In other words, human interference with descent, as a 'natural fact of life', is literally criminalized. It is, however, worth noting that these episodes largely reject the 'survival of the fittest' aspect of Darwin's genealogy. Instead, they are structured by the notion that 'natural' sexual reproduction will produce a healthy genetic diversity that allows for a wide variety of human beings, which are presented as being equally 'normal' no matter their physical appearance.

Furthermore, it is also indicative that in 'A Little Murder' the father's attempt to stop his daughter from potentially mothering a dwarf is ultimately unsuccessful; she is already pregnant when her fiancé is murdered. This twist implicitly constructs sexual reproduction and vertical descent as a 'natural' force always able to find a way to move forward and reassert itself as a basis for life (Franklin 2000: 198). This notion is also forcefully conveyed in the episode 'Spark of Life' where the forensic scientists investigate the death of a married couple (Morgan and Corinne), in parallel with the near fatal burning of a woman called Tara. The investigation reveals that Tara had gone through multiple unsuccessful in vitro fertilisation treatments with her infertile husband, after which their close friends Corinne and Morgan had suggested that Morgan could secretly impregnate her. However, when the husband accidently found out, he killed both Morgan and Corinne, and Tara subsequently attempted to take her own life. Apart from the episodes' dramatization of traditional patriarchal fears about female sexual infidelity and the problem of establishing biological paternity, much importance is placed on the fact that assisted reproduction technologies could not actually help Tara to conceive and that the 'spark of life' could only be ignited through traditional sexual intercourse with a fertile man. Furthermore, that Tara survives her severe burns is explicitly accredited to her pregnancy: she is carrying a new life that her body is 'programmed' to protect. 
CSI's treatment of kinship can thus be said to also articulate a decidedly conservative 'pro-life' perspective on reproduction, often voiced within public debates about abortion and stem-cell research in the US. The Lennart Nilsson-inspired footage of foetal development featured in the opening teaser of 'Secret and Flies' also evokes this pro-life discourse. Nilsson's work has been widely circulated in anti-abortion contexts, where it has been used as both affective illustrations of 'the miracle' of life itself and proof of the biological facts of foetal life (Stormer 1997: 172-91, Adams 1994: 141-42, Hartouni 1992: 135, Stabile 1992: 183-84). As Nathan Stromer points out, Nilsson's imagery has become associated with a certain type of anti-abortion rhetoric that 'constructs the reproductive body as an anchor for society', thus providing an imperative to preserve and maximize life (Stormer 1997: 174). These associations are fairly straightforwardly transferred onto CSI's foetal imagery, particularly as the sequence effectively conveys the idea of an unstoppable life-force by ending with a shot that juxtaposes the living baby with the lifeless body of the deceased mother. Following in the tradition of The Miracle of Life, CSI too is saturated by a broader 'pro-life' perspective on sex and reproduction that combines scientific, cultural and religious discourses which 'deems the creation of human life a value that supersedes cultural and individual consideration and that centralizes life's worth in reproductive structures and practices' (Stormer 1997: 173).

\section{Contradictory Views on Non-reproductive Sex and Non-normative Family Structures}

Apart from constructing sexual reproduction as a natural force that will always 'find a way', the episode 'Spark of Life' also constructs the nuclear family as a 'natural' and ideal site for reproduction when figuring Tara's struggles to conceive. One of the reasons why Tara's attempts result in multiple murders is because she forms a biological kinship bond outside of her own marriage. This is only one of many episodes in CSI that problematizes non-normative family structures. Post-divorce families, single parent families, and other types of familial structures that base kinship on mutual affective life and cohabitation (rather than shared genetic matter), are repeatedly featured as sites of crime in CSI. Tellingly, the programme often establishes strong narrative links between non-normative familial structures and nonreproductive sexual practices, the implication being that different forms of kinship bonds present a threat to the 'natural' forward-striving motion of Darwinian genealogy.

As has already been pointed out in previous scholarly writing on the programme, CSI frequently features a wide range of sexual subcultures. The lifestyles and sexual practices of sadomasochists; 'wife swappers'; 'plushies and furries'; 'biting fetishists'; 'vampires'; 'panty sniffers' and 'infantilists' - to mention only a few - are all problematized though a narrative association with violent crimes, which results in a necessary assumption that non-normative sex is dangerous (Rahilly 2007, Bull 2008, Lavigne 2009). As Lucia Rahilly has wittily put it: 'on CSI, love and sex almost invariably lead not to the selfobliterating pleasure of le petit mort but to actual fatality' (Rahilly 2007: 125). The programme specifically emphasizes the fetishist nature of these sexual practices, typically by spectacularizing the rituals and objects associated with the particular sexual activity. For example, the reoccurring plotlines focusing on sadomasochist communities feature lengthy displays of the masks, leather outfits, whips, ropes and chains used by the practitioners to stage elaborate role-playing sessions. This type of figuration implicitly suggests that the sadomasochists - and their peers - either omit the act of intercourse completely or primarily practice casual protected sex as part of a promiscuous lifestyle. 
This is a pre-copy edited version of an article accepted for publication in Journal of Popular Television (Volume 2, Issue 2, October 2014) following peer-review. The definitive publisher authenticated version is available from: http://www.intellectbooks.co.uk/journals/view-Article,id=18491/

[Figure 10: The sexual practices of 'plushies and furries' constructed as fetishist, promiscuous and non-reproductive in 'Fur and Loathing'.]

One representative episode that ties these specifically non-reproductive sexual practices to non-normative family structures is 'Swap Meet', in which the 'dark secrets' hiding behind the seemingly perfect picket fences and green lawns of suburban Las Vegas are revealed. The forensic scientists investigate the death of a woman who was killed after attending a neighbourhood 'swapping party'. When interviewing the hosts of the party, they find a dishwasher filled with dildos: an initial sign that the domestic bliss on offer in suburbia is no longer that which is traditionally associated with the ideal fifties housewife. The spouses are adamant that they are indeed happily married and that their domesticity is maintained and strengthened by finding sexual satisfaction elsewhere, at least as long as they follow a set of strict rules: 'No means no. Arrive as a couple, leave as a couple. Drugs never, condoms always. No affairs, sex with someone else is only allowed at the parties. No photos, no video. And the kids must never know.' Nevertheless, the investigation reveals that few of these rules have actually been upheld and that there are significant rifts in more than one of the families in the neighbourhood. A scene where a lab technician tests the insides and outsides of the 26 used condoms recovered from the swapping party ends with an illustrative image - drawn as a diagram on a whiteboard - of how a complex network of sexual relationships deconstructs the traditional nuclear family unit. Hence, forensic evidence proves that several guests have ongoing affairs outside the contexts of the parties and the swapping culture is ultimately portrayed as creating a number of problematic extra-familial relationships.

Furthermore, it is of narrative importance that the victim's own family already is a post-divorce family; she was killed by her teenage stepdaughter who found out she left the swapping party with a neighbouring husband, who was also sleeping with the teenager. Hence, the episode clearly articulates cultural worries about how non-normative family structures might affect the children. Throughout the episode, the kids of the wife swappers are constantly present in the periphery, both narratively and visually. Playing video games or sunbathing by the pool as the investigators process the houses or interviews the parents, the children seem preoccupied, but are in fact more involved in the events than the adults might think. The swapping culture, with its alternative social bonds and non-reproductive sexual practices, is thus presented as having produced both an underage murderer and a crossgenerational sexual relationship; both oppose normative ideas about childhood and 'appropriate' sexual relationships.

[Figures 11, 12 and 13: Suburban family life under investigation in 'Swap Meet'.]

Considered in relation to CSI's investment in traditional genetic kinship, unsuitable cross-generational sexual affairs, extra-familial bonds and non-reproductive sexual acts become understood as posing a threat to the 'natural order' of vertical descent. Fleeting social relationships are dramatized as lacking in both substance and significance, which presumably makes it much more difficult to produce reliable forensic proof of their existence. As a result, the nuclear family and biological reproduction are inadvertently idealized as frameworks for restoring a traditional Darwinist genealogy. However, while CSI entertains the fantasy of the nuclear family as a controlling framework for sex and reproduction, it still presents a narrative world where non-normative versions of kinship bonds and reproductive practices are ever present. For example, 'Swap Meet' could equally be understood as identifying the nuclear family as merely a superficial and unachievable ideal. The forensic 
This is a pre-copy edited version of an article accepted for publication in Journal of Popular Television (Volume 2, Issue 2, October 2014) following peer-review. The definitive publisher authenticated version is available from: http://www.intellectbooks.co.uk/journals/view-Article,id=18491/

investigation in this episode does establish that the normative nuclear families you might expect to find in suburbia are long lost, if they ever existed.

CSI's overall treatment of non-reproductive sexual practices is thus characterized by a certain ambiguity that Lindsay Steenberg has convincingly described as a result of the programme's 'tabloid mode of address': a tendency to depict non-normative sexual practices with large measures of sensationalism and moral panic, while at the same time constructing an 'alternative public sphere' where an array of issues usually ignored by 'the mainstream' can be discussed (Steenberg 2008: 32-4). In other words, CSI can be understood as creating a kind of liminal space where non-reproductive sexual practices and non-normative family structures are turned into 'tabloid spectacles' that simultaneously hold both 'a conservative charge as well as a subversive potential' (Steenberg 2008: 216). The programme's has indeed been heavily criticized by conservative and family-oriented lobbying groups for allegedly 'glorifying' non-normative and non-reproductive sexual practices. The Los Angeles-based Parents Television Council (PTC) has, for example, continually ranked CSI among its top ten 'Worst Shows on Network TV' and has initiated several campaigns to encourage its members to file complaints about specific CSI episodes to the Federal Communications Commission, primarily due to the programme's depiction of 'deviant and debauched' sexual behaviour outside the framework of marriage (Bowling 2005; Anon 2008).

I would argue that CSI's 'tabloid address' follows the rubrics set up by a successful cluster of 'quirky' television dramas from the 1990s, such as Picket Fences (199296), Twin Peaks (1990-91), Northern Exposure (1990-95) and X-Files (1993-2002), all of which used controversial subject matter as a method for attracting viewers in the increasingly competitive television landscape (Thompson 1997: 149-50). Picket Fences, in particular, can be identified as an important forerunner, partly because CSI's executive producer Ann Donahue previously worked as a supervising producer on Picket Fences. Donahue has explained that Picket Fences was created to be 'a First Amendment show', intended to celebrate 'everybody's right to their space, their religion, their death and their life' (Thompson 1997: 171). For example, Picket Fences featured a town priest with a shoe fetish, a transsexual schoolteacher, a husband suffocated by his wife's overweight body, and a 'serial bather' obsessed with using stranger's tubs. Such plots were careful crafted to deal with controversial issues in ambiguous ways, for example by having different characters express different perspectives (Thompson 1997: 172).

CSI has wholeheartedly adopted this device; the main characters often confront each other's bigotries and prejudices with regards to non-normative sexual practices and family structures. It is typically the team leader, Gil Grissom, who embodies a more liberal open-minded perspective, often to the extent that he himself is mistaken for himself being a member of various sexual subcultures. For example, in 'King Baby' (S05E15), a saleswoman in the infantilism store Forever Baby assumes that Grissom is a 'daddy' buying adult diapers for his colleague and in 'Big Middle' (S05E16) he allows a woman to think he is a 'chubby chaser'. Furthermore, one of the programme's more long-running plotlines centers on Grissom's romantic involvement with the dominatrix Lady Heather. As Steven Cohan has observed, Grissom's status as the most authoritative scientist of the team means that his openmindedness usually is presented as an ideal viewpoint (Cohan: 2008: 124-25). Curiosity and open-mindedness are generally portrayed as ideal traits that a forensic scientists should embody, but the series often concludes that it is 'only human' to be prejudiced or have more conservative values. Grissom's colleagues often voice more critical opinions about the nonnormative lifestyles depicted. For example, in 'Swap Meet' Sara Sidle admits to Grissom that she has a problem with the promiscuous lifestyle of the 'wife swappers'. While Grissom reminds her that these are consenting adults who only risk hurting themselves, Sara's 
perspective is ultimately validated by the fact that the swapping lifestyle evidently results in jealousy, heartbreak and even murder.

Finally, some of the programme's ambiguity also stems from its depiction of the forensic scientist's own kinship relationships, which certainly suggests that significant and enduring ties do exist between 'unfamiliars' without any biological bond (Haraway 1997: 265). In particular, the main members of the team (Gil Grissom, Catherine Willows, Sara Sidle, Nick Stokes, Warrick Brown and Greg Sanders) are all portrayed as sharing close bonds of mutual trust and love that are often explicitly depicted as substituting their generally dysfunctional familial relationships outside of work. For example, Catherine is a divorced single mother and grew up without knowing that the shady casino mogul Sam Braun is her biological father, Sara was raised in foster homes after her abusive mother murdered her father, and Warrick moved in with his grandmother when his mother died and father abandoned the family. In contrast to these unstable or severed biological bonds, the team is depicted as a close-knit group often enjoying family-type activities (such as bowling, driving go-karts or sharing meals) together. Much like other programmes featuring 'work families', CSI thus heralds social kinship bonds as being even more important for the happiness and identity of its main characters than their blood-ties.

[Figures 14 and 15: The 'work family' enjoying go-karting in 'A La Cart' (S08E02) and having breakfast together in 'Rashomama' (S06E21).]

However, this does not mean that the programme's portrayal of the work family is completely free from normative ideas. The relationships between the forensic scientists are, as Carlen Lavigne notes, governed by a traditional hierarchal structure that clearly emulates the ideal of the nuclear family: with 'a white male in charge of a crime lab, his white female second-in-command, and assorted underling 'children" (Lavigne 2009: 385). Hence, while the work family is depicted as providing more fulfilling and stable bonds than most bloodties, it still largely retains the conventional gender hierarchy associated with the traditional nuclear family.

\section{Conclusion}

This analysis has attempted to map the complex and socio-historically specific ideas about kinship and reproduction articulated in CSI. I have shown that the Darwinian framework of genealogy structures CSI's depiction of forensic science as able to establish reliable proof of kinship through DNA testing. Through a frequent symbolic use of the iconographies of likeness, blood and the family tree, the programme constructs genetic kinship as substantial, enduring and significant. However, the programme also engages with the post-genomic respatialization of genealogy that increasingly questions the traditional understanding of biological kinship. While it is still invested in sexual reproduction and vertical descent as 'natural facts of life', CSI at least acknowledges that the Darwinian notion of biological kinship is currently being redefined by new medico-scientific discoveries. The programme generally portrays non-reproductive sexual acts and non-normative family structures in ways that evoke conservative 'pro-life' perspectives and presents the nuclear family as an ideal framework for reproduction. However, CSI's 'tabloid address' also constructs a kind of liminal space where non-reproductive sexual practices and non-normative family structures are acknowledged and discussed. The programme is thus characterized by an ambiguous discourse on kinship that articulates multiple perspectives on how new developments in biomedicine and genetics impact ideas about familial relationships, family structures and reproduction practices. 
While the article has focused solely on CSI, this is only one of many contemporary television programmes that discuss new assisted reproduction practices as crucial for producing non-normative family structures and familial relationships that fundamentally question traditional ideas about kinship. Here I am not only thinking of other forensic crime dramas, such as CSI's spin-off series CSI: Miami (2002-12) and CSI: NY (2004-13), but also a wide range of programmes including Inconceivable (2005); Modern Family (2009-); Test Tube Babies (2010); A Conception Story (2010); The New Normal (2012-); Baby Makers: The Fertility Clinique (2013); Utopia (2013); and The Fosters (2013). The issue of how our increased ability to intervene with the reproduction process impacts our understanding of kinship is currently being discussed across a wide range of different genres and CSI is only one facet of the television medium's cultural forum on this issue (Newcomb and Hirsch, 1981).

\section{References}

Adams, Alice. (1994) Reproducing the Womb: Images of Childbirth in Science, Feminist Theory, and Literature. Ithaca: Cornell University Press.

Anon. (2008) A Parents Television Council Special Report: Happily Ever After: How Hollywood Favours Adultery and Promiscuity Over Marital Intimacy on Prime Time Broadcast Television, http://www.parentstv.org/PTC/news/release/2008/0805.asp. Accessed November 15, 2011.

Belk, Russel W. (1996) 'On Aura, Illusion, Escape and Hope in Apocalyptic Consumption: The apotheosis of Las Vegas' in Stephen Brown, Jim Bell and David Carson, (eds.) Marketing Apocalypse: Eschatology, Escapology and the Illusion of the End, London: Routledge, pp. 89-111.

Bowling, Aubree. (2005) 'Parents Television Council Presents: Worst TV Show of the Week, CSI: Crime Scene Investigation on CBS', PTC website, http://www.parentstv.org/PTC/publications/bw/2005/0220worst.asp. Accessed August 5, 2007.

Bull, Sofia. (2008) 'What Happens in Vegas Stays in Vegas: Sexual Subcultures and Forensic Science in CSI: Crime Scene Investigation', Film International, Issue 36, pp. 40-50.

Burr, Vivien and Christine Jarvis. (2005) 'Friends are the family we choose for ourselves: Young people and families in the TV series Buffy the Vampire Slayer', Young: Nordic Journal of Youth Research, Vol. 13, No. 3, pp. 269-83.

Burr, Vivien and Christine Jarvis. (2007) Imagining the Family: Representations of Alternative Lifestyles in Buffy the Vampire Slayer', Qualitative Social Work, vol. 6, no. 3, pp. 263-80.

Caldwell, John Thornton. (1995) Televisuality: Style, Crisis, and Authority in American Television. New Brunswick, New Jersey: Rutgers University Press.

Cantor, M. G. (1991) 'The American family on television: From Molly Goldberg to Bill Cosby', Journal of Comparative Family Studies, 22, pp. 205-16. 
Carsten, Janet. (2001) 'Substantivism, Antisubstantivism, and Anti-antisubstantivism' in Sarah Franklin and Susan McKinnon (eds.) Relative Values: Reconfiguring Kinship Studies, Durham and London: Duke University Press, pp. 29-53.

Cohan, Steven. (2008) TV Classics: CSI: Crime Scene Investigation. London: BFI Publishing.

Dates, Jannette L. and Carolyn A. Stroman, (2001) 'Portrayals of Families of Color on Television' in Jennings Bryant and J. Alison Bryant (eds.) Television and the American Family, Second Edition, Mahwah: Lawrence Erlbaum Associates, pp. 207-28.

Douglas, William and Beth M. Olson. (1995) Beyond Family Structure: The Family in Domestic Comedy', Journal of Broadcasting and Electronic Media. Vol. 39, no. 2, pp. 23661 .

Douglas, William. (1996) 'The Fall From Grace: The Modern Family in Television', Communications Research, vol. 23, no.6, pp. 675-701.

Douglas, William. (2003) Television Families: Is Something Wrong in Suburbia. London and New York: Routledge.

Douglas, Williams. (2001) 'Subversion of the American Television Family' in Jennings Bryant and J. Alison Bryant (eds.) Television and the American Family, Second Edition, Mahwah: Lawrence Erlbaum Associates, pp. 229-46.

Bryant, Jennings (ed.) (1990) Television and the American Family, Hillsdale: Lawrence Erlbaum Associates.

Bryant, Jennings and J. Alison Bryant (eds.) (2001) Television and the American Family, Second Edition Mahwah: Lawrence Erlbaum Associates.

Edwards, Leigh H. (2010) 'Reality TV and the American Family', in Julie Anne Taddeo and Ken Dvorak (eds.) The Tube Has Spoken: Reality TV and History, Lexington: University Press of Kentucky, pp. 123-44.

Franklin, Sarah. (2000) 'Global Nature and the Genetic Imaginary' in Sarah Franklin, Celia Lury and Jackie Stacey (eds.) Global Nature, Global Culture, London: SAGE Publications, pp. 188-227.

Haraway, Donna.(1997)Modest_Witness@Second_Millennium.FemaleMan_Meets_OncoMouse: Feminism and Technoscience. New York and London: Routledge.

Heintz-Knowles, Katherine. (2001) Balancing Acts: Work-Family Issues on Prime-Time TV', in Jennings Bryant and J. Alison Bryant (eds.) Television and the American Family, Second Edition, Mahwah: Lawrence Erlbaum Associates, pp.177-206.

Holmes, Su. (2010) 'The television audience cannot be expected to bear too much reality': The Family and Reality TV' in Julie Anne Taddeo and Ken Dvorak (eds.) The Tube Has Spoken: Reality TV and History, Lexington: University Press of Kentucky, pp. 99-122. 
Jermyn, Deborah. (2007) Crime Watching: Investigating Real Crime TV. London and New York: I.B. Tauris.

Keeler, Amanda R. (2010) Branding the Family Drama: Genre Formations and Critical Perspectives on Gilmore Girls, in David Scott Diffrient and David Lavery (eds.) Screwball Television: Critical Perspectives on Gilmore Girls, Syracuse: Syracuse University Press, pp. 19-35.

Keller, Evelyn Fox. (2005) 'The Century Beyond the Gene', Journal of Bioscience, 30(1), pp. $3-10$.

Kompare, Derek. (2010) CSI, Malden: Wiley-Blackwell.

Lavigne, Carlen. (2009) 'Death Wore Black Chiffon: Sex and Gender in CSI', Canadian Review of American Studies, 39, no.4, pp. 383-98.

Leibman, Nina C. (1995) Living Room Lectures: The Fifties Family in Film and Television. Austin: University of Texas Press.

Ley, Barbara, Nathalie Jankowski and Paul R. Brewer. (2010) 'Investigating CSI: Portrayals of DNA testing on a forensic crime show and their potential effects', Public Understanding of Science, May 27, pp. 1-17.

Linné, Olga and Paul Hartmann. (1966) 'Family Differences on Television', European Journal of Communication, Vol. 1, pp. 407-20.

Lull, James. (1990) Inside Family Viewing: Ethnographic Research on Television's Audiences. London and New York: Routledge.

Mahajan, Amar Jit and Nirupama Luthra. (1993) Family and Television. New Delih: Gyan Publishing House.

Moore, Marvin L. (1992) 'The Family as Portrayed on Prime-Time Television, 1947-1999: Structure and Characteristics'Sex Roles, Vol. 26. No. 1/2, pp. 41-61.

Murray, Michael D. (1990) 'A Real-Life Family in Prime Time' in Jennings Bryant (ed.) Television and the American Family, Hillsdale: Lawrence Erlbaum Associates. pp. 185-92.

Nash, Catherine. (2002) 'Genealogical Identities', Environment and Planning D: Society and Space, Vol. 20, pp. 27-52.

Nash, Catherine. (2004) 'Genetic Kinship’, Cultural Studies, 18:1, pp. 1-33.

Nash, Catherine. (2005) 'Geographies of Relatedness', Trans Inst Br Geogr, 30(4), pp. 44962.

Newcomb, Horace M. and Paul M. Hirsch. (1983), 'Television as a Cultural Forum: Implications for Research', Quarterly Review of Film Studies, 8:3, 1983, pp. 45-55. 
Nilsson, Lennart (1983) The Miracle of Life, United States: Nova/PBS.

Nilsson, Lennart (2000) The Miracle of Love, Sweden/United States: SVT/PBS.

Nilsson, Lennart (2001) Life's Greatest Miracle, United States: Nova/PBS.

Nilsson, Lennart and A. Ingelman-Sundberg (1965) A Child is Born: The Drama of Life Before Birth. New York: Seymour Lawrence/Delacorte Press.

Oueliette, Laurie. (2014) 'It's Not TV, It's Birth Control: Teality Television and the 'Problem' of Teenage Pregnancy', in Brenda R. Weber (ed.) Reality Gendervision: Sexuality and Gender on Transatlantic Reality Television, Durham/London: Duke University Press, pp. 235-58.

Pingree, Suzanne and Margaret E. Thompson. (1990) 'The Family in Daytime Serials' in Jennings Bryant (ed.) Television and the American Family, Hillsdale: Lawrence Erlbaum Associates. pp. 113-28.

Pramaggiore, Maria and Diane Negra. (2014) Keeping Up with the Aspirations: Commercial Family Values and the Kardashian Brand', in Brenda R. Weber (ed.) Reality Gendervision: Sexuality and Gender on Transatlantic Reality Television, Durham/London: Duke University Press, pp. 76-96.

Rahilly, Lucia. (2007) 'The Quintessence of Con: The Las Vegas of CSI' in Michael Allen (ed.) Reading CSI: Crime TV Under the Microscope, London: I.B. Tauris, pp. 122-5.

Rapping, Elayne. (2003) Law and Justice as Seen on TV. New York and London: New York University Press.

Reep, Diana C. and Faye H. Dambrot. (1994), 'TV Parents: Fathers (and now Mothers) Know Best', The Journal of Popular Culture, vol. 28, issue 2, pp. 13-23.

Robinson, D. James and Thomas Skill, (2001) Five Decades of Families on Television: From the 1950s through the 1990s', in Jennings Bryant and J. Alison Bryant (eds.) Television and the American Family, Second Edition, Mahwah: Lawrence Erlbaum Associates, pp. 139-62.

Rose, Nikolas. (2007) The Politics of Life Itself: Biomedicine, Power, and Subjectivity in the Twenty-First Century. Princeton: Princeton University Press.

Rupert, Laurie and Sayanti Ganguly Puckett. (2010) 'Disillusionment, Divorce and the Destruction of the American Dream: An American Family and the Rise of Reality TV', in Julie Anne Taddeo and Ken Dvorak (eds.) The Tube Has Spoken: Reality TV and History, Lexington: University Press of Kentucky, pp. 83-98

Sandell, Jullian. (1998) I'll Be There For You: Friends and the Fantasy of Alternative Families', American Studies, 39:2, pp. 141-55 
Schneider, David. (1980) American Kinship: A Cultural Account, 2nd edition. Chicago: University of Chicago.

Spigel, Lynn. (1992), Make Room for TV: Television and the Family Ideal in Postwar America. Chicago and London: Chicago University Press.

Stabile, Carol A. (1992) 'Shooting the Mother: Foetal Photography and the Politics of Disappearance', Paula A. Treichler and Lisa Cartwright (eds.) Camera Obscura (Special Issue: Imaging Technologies, Inscribing Science), Vol. 10, No. 1, pp. 176-205.

Stacey, Jackie. (2010) Cinematic Life of the Gene. Durham and London: Duke University Press.

Steenberg, Lindsay. (2008) 'Sexy/Dead: Gender and Forensic Science in the Contemporary Crime Thriller’, PhD thesis, Norwich: The University of East Anglia.

Stephens, Rebecca. (2014) 'Supersizing the Family: Nation, Gender and Recession on Reality TV' in Brenda R. Weber (ed.) Reality Gendervision: Sexuality and Gender on Transatlantic Reality Television, Durham/London: Duke University Press, pp. 170-91.

Stormer, Nathan. (1997) 'Embodying Normal Miracles', Quarterly Journal of Speech, no. 83, pp. 172-91.

Strathern, Marilyn. (1992) Reproducing the Future: Anthropology, Kinship and the New Reproductive Technologies. Manchester: Manchester University Press.

Taylor, Ella. (1989) Prime-Time Families: Television Culture in Post-War America, Berkley: University of California Press.

Thompson, Robert J. (1997) Television's Second Golden Age: from Hill Street blues to ER. Syracuse University Press.

Villarejo, Amy. (2014) Ethereal Queer: Television, Historicity, Desire. Durham/London: Duke University Press.

Weston, Kath. (2001) Kinship, Controversy, and the Sharing of Substance: The Race/Class Politics of Blood Transfusion' in Sarah Franklin and Susan McKinnon (eds.) Relative Values: Reconfiguring Kinship Studies, Durham/London: Duke University Press, pp. 147-74.

Young, Alison. (1996) Imaging Crime: Textual Outlaws and Criminal Conversations. London: SAGE Publications.

\section{List of Television Programmes}

Twin Peaks (1990-91, United States: ABC)

Northern Exposure (1990-95, United States: CBS)

Picket Fences (1992-96, United States: CBS)

$X$-Files (1993-2002, United States: Fox)

CSI: Crime Scene Investigation (2000-, United States: CBS)

'A Little Murder' (season three, episode four:) 
'Feeling the Heat' (season four, episode four:)

'Fur and Loathing' (season four, episode five:)

'Bloodlines' (season four, episode twentytree)

'Swap Meet' (season five, epiosde five)

'King Baby' (season five, episode fifteen)

'Big Middle' (season five, epsode sixteen)

'Spark of Life' (season five, episode eighteen)

'Secrets and Flies' (season six, episode six)

'Still Life' (season six, episode ten)

'Werewolves' (season six, episode eleven)

'Rashomama' (season six, episode twentyone).

'Happenstance' (season seven, episode eight)

'A La Cart' (season eight, episode two)

'Genetic Disorder' (season twelve, episode ten)

CSI: Miami (2002-12, United States: CBS)

CSI: NY (2004-13, United States: CBS)

Inconceivable (2005, United States: NBC)

Modern Family (2009-, United States: ABC)

A Conception Story (2010, United States: TLC)

Test Tube Babies (2010, United States: PBS)

The New Normal (2012-, United States: NBC)

Baby Makers: The Fertility Clinique (2013, United Kingdom: BBC)

The Fosters (2013-, United States: ABC)

Utopia (2013-, United Kingdom: Channel 4) 